Short Communication

\title{
Production and purification of xylooligosaccharides from oil palm empty fruit bunch fibre by a non-isothermal process
}

\author{
Ai Ling Ho ${ }^{a}$, Florbela Carvalheiro ${ }^{\mathrm{b}}$, Luís C. Duarte ${ }^{\mathrm{b}}$, Luísa B. Roseiro ${ }^{\mathrm{b}}$, Dimitris Charalampopoulos ${ }^{\mathrm{a}}$, \\ Robert A. Rastall ${ }^{\text {a,* }}$ \\ a Department of Food and Nutritional Sciences, University of Reading, Whiteknights, P.O. Box 226, Reading RG6 6AP, United Kingdom \\ ${ }^{\mathrm{b}}$ LNEG, Unidade de Bioenergia, Estrada do Paço do Lumiar 22, 1649-038 Lisboa, Portugal
}

\section{H I G H L I G H T S}

- Information on oligosaccharides production from oil palm biomass is very scarce.

- Oligosaccharides production from OPEFB fibre via autohydrolysis is demonstrated.

- Substantial yield of XOS is achieved using non-isothermal conditions.

- High purity of refined XOS with wide ranges of DP were obtained.

\section{A R T I C L E I N F O}

\section{Article history:}

Received 28 August 2013

Received in revised form 28 October 2013

Accepted 30 October 2013

Available online 8 November 2013

\section{Keywords:}

Autohydrolysis

Gel filtration chromatography

Oil palm empty fruit bunch

Xylooligosaccharides

\begin{abstract}
A B S T R A C T
Oil palm empty fruit bunches (OPEFB) fibre, a by-product generated from non-woody, tropical perennial oil palm crop was evaluated for xylooligosaccharides (XOS) production. Samples of OPEFB fibre were subjected to non-isothermal autohydrolysis treatment using a temperature range from 150 to $220^{\circ} \mathrm{C}$. The highest XOS concentration, $17.6 \mathrm{~g} / \mathrm{L}$ which relayed from solubilisation of $63 \mathrm{~g} / 100 \mathrm{~g}$ xylan was achieved at $210^{\circ} \mathrm{C}$ and there was a minimum amount of xylose and furfural being produced. The chromatographic purification which was undertaken to purify the oligosaccharide-rich liquor resulted in a product with $74-78 \%$ purity, of which $83-85 \%$ was XOS with degree of polymerisation (DP) between 5 and 40 .
\end{abstract}

(c) 2013 Elsevier Ltd. All rights reserved.

\section{Introduction}

A new wave of novel of non-digestible oligosaccharide (NDO) prebiotic candidates is emerging such as pectic oligosaccharides and xylooligosaccharides (XOS), which are obtained from plant cell wall polysaccharides of agro-industrial or agricultural wastes (Manderson et al., 2005; Parajó et al., 2004). The potential of these NDOs lies not only in their potential nutraceutical properties, but also in their economic benefits as they constitute an opportunity for agro-food industries to re-capture value from wastes and indirectly improves the environment through reduction of agro-food wastes and the costs associated with their management.

Hydrothermal treatments such as autohydrolysis have been investigated as the practical processes for obtaining oligosaccharides, as these treatments enable the hemicelluloses to be hydrolysed selectively in a relatively short time (Garrote and Parajó, 2002). This hydrolysis mechanism has been well described in the

\footnotetext{
* Corresponding author. Tel.: +44 118378 6726; fax: +44 1189310080 .

E-mail address: r.a.rastall@reading.ac.uk (R.A. Rastall).
}

literature (Belkacemi et al., 1991; Carvalheiro et al., 2008; Garrote et al., 2002; Moure et al., 2006). Since only water is used in the process as compared to acid hydrolysis, equipment corrosion and impact on the environment are reduced (Carvalheiro et al., 2008). Nevertheless, optimisation of operational conditions is required to minimise reaction by-products such as monosaccharides and sugar degradation compounds generated from oligosaccharides thus decreasing yield. Acetic acid (a structural component of hemicelluloses) is typically also present in autohydrolysis liquors. These need to be removed to produce XOS with high purity (Moure et al., 2006).

Most of the feedstock sources for XOS production studied to date have been wastes from crops of temperate climates. An alternative tropical crop source, largely from South East Asia, is oil palm (Elaeis guineensis Jacq.) wastes. Lignocellulosic residues arise from oil palm biomass either as mill by-products (oil palm empty fruit bunches - OPEFB) or field by-products (oil palm frond and trunks). The upgrade of these biomass sources, especially from the mill derived by-products such as OPEFB, is now considered an important research topic due to the potential economic impact that could be 